\title{
David Oliver: Collectivism and selfishness in NHS users
}

\author{
David Oliver, consultant in geriatrics and acute general medicine
}

Berkshire

Holborn underground station in London recently announced a six month trial of standing on both sides of escalators, rather than standing on the right and leaving the left for overtaking. ${ }^{1}$ An earlier pilot had shown that this moved people through the station $30 \%$ more quickly overall, even at the expense of a minority who wanted to charge up the left hand side.

Complaints ensued from some passengers that their personal right to speedier ascent was infringed ${ }^{2}$ like self justifying individuals complaining about motorway speed limits: safety and traffic flow for the many be damned! $!^{3}$ It's the same with giant bags filling lockers on planes.

Now consider Christian Solomonides, an emergency doctor who was suspended by the General Medical Council after making dozens of tweets castigating people for frivolous use of ambulances, needless hospital attendance, and selfish behaviour when they arrived. ${ }^{4}$ Unwise? Perhaps-but he's hardly the first doctor or paramedic to share these frustrations.

In my work, most patients and families are very public spirited. But I have seen self interested behaviour. Some relatives repeatedly doorstep doctors and nurses attending to equally needy sick or dying patients with equally worried families. Others are oblivious to a wider population desperate for limited beds, holding the hospital to ransom when their loved one needs to go home.

I and my colleagues have heard some unashamedly say, "I don't care about anyone else-just my mum/dad." Still, I'm dead against charging or blaming patients, ${ }^{5}$ as well as disparaging terms such as "bed blocker."

People largely remain proud of the $\mathrm{NHS}^{7}$ and satisfaction levels are high-especially in those using it recently or often. ${ }^{8}$ But we're a more individualistic, consumerist society than when it was founded.

The "other people need the bed" or "I didn't want to bother anyone" attitudes I still encounter among older patients may be waning in people who are used to booking a hotel online in 10 minutes, with pictures and reviews. Younger people are less wedded to the current NHS model, are less grateful for it than previous generations, and generally use it infrequently. ${ }^{9}$
Journalists such as Matthew Parris and Sarah Baxter have written about their desire to cut out GPs as gatekeepers and go straight to secondary care ${ }^{10}{ }^{11}$; others write about the need for slicker appointments or concierge GPs. General practice and urgent care face triple crises around demand, workforce, and funding; and the NHS, by Western standards, is poorly funded. ${ }^{12}$

Maybe those who don't want to stand on the right of the escalator should be given the means to opt out of a public collectivist system that prioritises the needs of a group over the wants of the individual. But Holborn's escalators were most efficient when everybody stood together.

Competing interests: See www.bmj.com/about-bmj/freelancecontributors/david-oliver.

Provenance and peer review: Commissioned; not externally peer reviewed.

1 BBC News. Holborn tube to trial standing-only escalators for second time. 10 Mar 2016 www.bbc.co.uk/news/uk-england-london-35770865.

2 Young T. We Londoners will explode with rage if we have to stand on the escalator. Telegraph 2016 Mar 10. www.telegraph.co.uk/news/uknews/road-and-rail-transport/ 12190266/We-Londoners-will-explode-with-rage-if-we-have-to-stand-on-the-escalator html.

3 Lovejoy B. Why councils can't be trusted to set speed limits. 1998. Available at www. speedlimit.org.uk/art speedchange.html.

Gibbons K. Doctor who tweeted rants about A\&E keeps his job. Times 2016 Mar 5. www. thetimes.co.uk/tto/health/news/article4706139.ece.

5 Oliver D. David Oliver: Stop blaming patients for emergency visits. BMJ 2015;351:h6119. doi:10.1136/bmj.h6119 pmid:26566636.

6 Oliver D. Minding our language around care for older people and why it matters. BMJ Blog 2015 May 7. http://blogs.bmj.com/bmj/2015/05/07/david-oliver-minding-our-languagearound-care-for-older-people/.

7 Dore $\mathrm{L}$. The NHS tops the list of things that make people most proud to be British. Independent $2016 \mathrm{Feb}$. http://indy 100.independent.co.uk/article/the-nhs-tops-the-list-ofthings-that-make-people-most-proud-to-be-british--bkl_jiMCpl.

8 King's Fund. British public's satisfaction with the NHS falls by five percentage points. 9 Feb 2016. www.kingsfund.org.uk/press/press-releases/public-satisfaction-nhs-falls-fivepercentage-points.

9 Helm T, Boffey D, Doward J. NHS crisis grows as young Britons turn their backs on family doctors. Guardian 2014 Dec 20. www.theguardian.com/society/2014/dec/20/nhs-crisisyoung-health-family-doctors.

10 Parris M. GPs-little more than glorified receptionists. Times 2012 Jun 16. www.thetimes. co.uk/tto/opinion/columnists/matthewparris/article3447349.ece.

11 Baxter S. If GPs can't be bothered with us, let's go straight to the chemist. Sunday Times 2016 Jan 31. www.thesundaytimes.co.uk/sto/comment/columns/SarahBaxter/ article1662348.ece.

12 Economist Intelligence Unit. The NHS: how does it compare? May 2015. www.eiu.com/ public/topical_report.aspx?campaignid=NHScomparison2015. 
Published by the BMJ Publishing Group Limited. For permission to use (where not already granted under a licence) please go to http://group.bmj.com/group/rights-licensing/

permissions 